\title{
Indonesian Young Adults' Interference in Translating English Cursing
}

\author{
Indra Nugraha \\ Faculty of Humanities, Universitas Padjadjaran \\ 21 Bandung-Sumedang Street, Jatinangor, Sumedang 45363, Indonesia \\ Tel: +62-22-87920401Ｅ-mail: indra11015@student.unpad.ac.id
}

Received: 01-06-2013

Accepted: 02-07-2013

Published: 01-09-2013

doi:10.7575/aiac.ijalel.v.2n.5p.167

URL: http://dx.doi.org/10.7575/aiac.ijalel.v.2n.5p.167

\begin{abstract}
Interference has become a crucial matter to recognize in bilingual and multilingual communities. The phenomenon of interference has affected how we as at least members of bilingual or even multilingual communities speak to the others. As the members of multilingual communities, the Indonesian young adults receive many influences in the way they speak and understand languages. However, these influences often lead to the wrong way. In this case, many Indonesian young adults understand English cursing inappropriately. This misunderstanding may lead to the abuse of English cursing in daily conversations. This article provides the insight of how interference affects the way the Indonesian young adults understand English cursing. Using the questionnaire-based research method, this articles tends to find out the attitudes of Indonesian young adults towards translating English cursing to Indonesian, which interference that affects the translation process of English cursing resulting to the inappropriate understanding of English cursing among Indonesian young adults, and which suitable translation method for translating English cursing to Indonesian. Apparently, the present writer has found out that there are two attitudes towards translating English cursing to Indonesian, that is, first, the English cursing is translated to the Indonesian cursing and second, the English cursing is translated literaly to Indonesian. Further, the present writer has found out that the interlingual interference has affected the translation process of English cursing to Indonesian and the suitable method for translating English cursing to Indonesian is adaptation based on Newmark (1988).
\end{abstract}

Keywords: Interference, Multilingual communities, Translating English cursing, Indonesian young adults

\section{Introduction}

One of the human interactions is conversations. A conversation involves many factors such as speakers, listeners, topics of the conversations and many more. In conversations, there can be found the use of language variations. One of them is the use of cursing. The use of cursing is treated negatively. Jay (2000) states:

Cursing is the utterance of emotionally powerful, offensive words (e.g. fuck, shit) or emotionally harmful expressions (e.g. kiss my ass, piss off, up yours) that are understood as insults. (p. 9)

Cursing can be used by and to anyone and it depends on the speaker.

Regarding the use of cursing, it cannot be separated from the aspect of culture because cursing is quite attached to culture. Every speech community has its own concept of cursing relating to its culture. Due to this difference of culture, a problem arises. The problem refers to the understanding of foreign cursing.

In multilingual communities such as in Indonesia, many Indonesian are faced with using more than one or two languages. Many of Indonesian themselves are multilingual. The first language of many Indonesian is their ethnic language, then the second is Indonesian, and the third one is the foreign language. This foreign language can be referred to English, Chinese, Japanese, French, German, etc. However, English is the most spoken language of all. Thus, English has influenced many aspects in Indonesian conversations especially young adults.

The influences of English come from many popular cultures such as movies and songs. Unfortunately, these influences have become quite strong so that it cannot be 'controlled' which ones are good and which ones are not. The good one may exist, but the bad ones may lead to the wrong way and one of them is the use of cursing in daily conversations. This use of cursing is due to the fact that there has been misunderstanding of English cursing because there is interference in the translation process of English cursing to Indonesian. This misunderstanding refers to the fact that there is hierarchy structure in cursing concept. There is level of offensiveness of cursing. The more offensive the curse words are the less they are used in conversations and otherwise (Jay, 2000). However, in the translation process of cursing, this concept seems to be ignored. This ignorance may result to the misunderstanding of the concept of English cursing among the Indonesian, especially young adults. Thus, the questions research of this article are what attitudes of Indonesian young adults towards translating English cursing to Indonesian? Which intereference that affects the translations process of English cursing resulting to the inappropriate use of English cursing among Indonesian young adults? And which suitable translation method for translating English cursing to Indonesian? 


\section{Theoretical Background}

In multilingual communities, language contact is such an inevitable matter. Through this language contact, the members of the speech communities receive many influences in using language. These influences can be considered as interference. Interference can be seen as in language transfer. Richard (1985) proposes:

Language transfer is the effect of one language on the learning of another language. Negative transfer or interference is the use of a native language pattern or rule which leads to an error or inappropriate form in the target language. (p. 160)

It can be concluded that the effect resulted in language transfer can be recognized as negative transfer or interference which comes from the native language of the speakers.

In multilingual communities, many people are aware of the importance of learning and mastering more than one language. However, in learning new languages, it often leads to language error. This error can also be called interlanguage or interference (Richard, 1985). The errors in learning language are affected by several factors. Richard (1985) refers these factors to:

(1) Borrowing patterns from the mother tongue, (2) extending patterns from the target language, (3) expressing meanings using the words and grammar which are already known. (p. 145-146)

Generally, interference can also be related to error analysis. Richard (1985) states there are two types of error:

(1) Interlingual error is an error which results from language transfer, that is which is caused by the learner's native language, (2) intralingual error is one which results from faulty or partial learning of the target language, rather than from language transfer. (p. 146)

Basically, these two types of error affect the way the members of multilingual communities learn, understand, and use language.

The phenomenon of interference cannot be saparated from the aspect of culture. Ervin-Tripp (1974) (cited in Garcia, 2005) states:

Interference error occur only when the second language learner is forced to generate sentence about semantically difficult material or concepts unfamiliar in the new language. (p. 26)

This is the same as the idea proposed by Richard (1985) that language learners will find difficulty in expressing meanings in foreign language because they are lack of grammar and vocabulary. Thus, it is quite hard to express meanings which often relate to culture in foreign language. This case can be seen in expressing and translating curse words.

Cursing is tied up to culture. Culture can define dan treat differently regarding the concept of cursing. One of the example that can be recognized is the hierarchy structure of curse words. This hierarchy refers to the level of offensiveness of curse words. Further, this level of offensiveness can be varied. For example in the United States, the curse words 'Fuck' belongs to $4^{\text {th }}$ level of the most offensive cursing (Sapolksy et al, 2008). Meanwhile, in the United Kingdom, the curse word 'Fuck' belongs to the $3^{\text {rd }}$ level of the most offensive cursing (Leigh and Lepine, 2005). This variation is due to the difference of understanding of members of the communities and culture. Further, Hughes (2006) states:

Swearing now includes so many varied and developed forms that some broad distinctions need to be made at the outset. (p. xv)

Thus, it is clear that regarding the concept of cursing, it needs to be treated carefully that cultural concepts such as the level of offensiveness also must be considered.

Regarding the curse words, there is no way that curse words of one's language can be fully understood by the others who are non-native. This also applies to those who are bilingual or even multilingual no matter how fluent they are. McManis (1987) proposes:

Another observable difference between native speakers and non-native but reasonably fluent speakers involves their treatment of taboo words. Words like shit, piss, and fuck elicit strong reaction from native speakers of English, reflecting years of experiences with people in their culture who were shocked and offended by the use of these words on inappropriate occasions. But non-native speakers, lacking extensive firsthand experience with the culture whose language they command to some extent, often do not have the same strong reaction to foreign taboo words. Thus they may feel considerably less inhibited in using them. (p. 325)

Due to this lacking experience and the difference of culture, many non-native speakers of English do not have the same 'feeling' in the way they treat and use English cursing. Furthermore, the meaning of cursing is connotative. In understanding cursing, it must refers to the connotative meanings not the denotative ones (Jay and Janschewitz, 2008). The lack of understanding English curse words affects the way they are understood and translated into another language, and in this case is Indonesian.

Talking about translation, then it is related to two different languages. Generally, the translation itself is a process transferring messages (Newmark, 1988). In the translation process, there are two important things, that is, 'process' and 'product' of translation. The 'process' of translation refers to how to transfer messages from source language to target language. Meanwhile, the 'product' of translation refers to the result of the translation. Regarding these two matters in 
translation, Shuttleworth and Cowie (1997, p. 181) states (cited in Hatim and Munday, 2004):

The first of these two senses relates to translation as the process, the second to the product. This immediately means that the term translation encompasses very distinct perspective. The first sense focuses on the role of the translator in taking the original or Source Text (ST) and turning it into a text in another language (the Target Text, TT). The second sense centres on the concrete translation product produced by the translator. (p. 3)

Thus, it can be concluded that both process and product of translation are related to each others because the translation itself is not a short process. A translation process is a long complex process involving many considered steps.

Besides those process and product of translation, there is another matter that must be considered, that is the intention of the text. The intention of the text plays a very important role because it can affects the process of translation. Newmark (1988) proposes:

The intention of the text represents the SL writer's attitude to the subject matter. (p. 12)

Then, it is clear that the intention of the text relates to the attitude of the writer of the text towards the topic of the text. Further, the intention of the text is the representation of the writer's attitude of the source language text to the main subject of the text. In the translation process, a translator must translate the text of the source language into the target language without changing the attitude of the source language writer represented by the intention of the text. Thus, in order to be understood by the reader of the target language, the tranlator cannot change the intention of the text of the source language (Newmark, 1988).

Another matter that must be considered in the translation process is the reader of the target language. The readers of the text must be also considered so that the message of the text can be transferred, and the way to do this is by using a proper method that is suitable to the 'character' of the text (Newmark, 1988).

As it is stated before, the translation process involving two different languages cannot be separated from culture. In a translation process, the involvement of culture can be complicated. This is due to the fact that the culture involved does not come only from the source language but also from the target language. Bassnett (2002) states:

Once the principle is accepted that sameness cannot exist between two languages, it becomes possible to approach the question of loss and gain in the translation process. (p. 38)

From the statement above, it can be concluded that there will be no such thing as the exact words both of source language and target language when it comes to translation process. furthermore, there is a concept of loss and gain. This concept of loss and gain is strictly related to culture. With the sufficient knowledge of culture, the translated texts can be comprehensive enough to understand and the intention of the texts can be transferred successfully (Al-Hassan, 2013). However, this concept of loss and gain seems to be ignored in translating English curse words to Indonesian. The level of offensiveness of English curse words seems 'lost' when they are translated to Indonesia, but they do not 'gain' the same concept in Indonesian regarding the level of their offensiveness. This indicates that they are not translated properly which may lead to the misunderstanding of English cursing by the Indonesian.

In order to transfer the intention and the message of the text correctly, the translation method must also be considered. Newmark (1988) proposes several methods of translation:

(1) Word-for-word translation: this method of translation emphasizes on the source language text. This translation method maintains the structure of the word order of the source language text when the text is translated into the target language. The purpose of this method is to understand the mechanism of the source language text and also to understand a complex text.

(2) Literal translation: this method focuses on the grammatical structure. The results of the translation adjusts the grammatical structure of the target language.

(3) Faithful translation: this method concerns about the contextual meaning. The method tries to replicate or adjust the contextual meaning of the source language text with the target language text in the way of target language grammatical structure.

(4) Semantic translation: this method has the same perception as the faithful translation. This same perception is related to the point of view of meaning especially when it comes to contextual meaning related to cultural aspect.

(5) Adaptation: the method emphasizez on the target language. The adaptation method is usually used to translate matters concerned with cultural aspect. Thus, this method is suitable to translate cultural aspects.

(6) Free translation: this method also focuses on target language. The method tries to reproduce the messages of the text.

(7) Idiomatic translation: this method transfers the message of the source language text by adjusting it to colloquial expressions and idioms existed in the target language.

(8) Communicative translation: this method tries the contextual meaning of the source language text as in the exact way as in the target language by referring it to the acceptable expressions of the target language.

Regading the young adults, they can be characterized between the age of 18 and 24 (Jekielek and Brown, 2005). Meanwhile, the ACS (Australian Community Survey) proposes that young adults are characterized between the age of 20 and 29. 


\section{Method}

\subsection{Participants}

Participants involved in this study are fifthy Indonesian young adults with the age between 18 and 26 years lod. They are random students from various universities in Bandung, Indonesia.

\subsection{Materials}

To support this study, the present writer uses a list of English and Indonesian curse words. Before, the present writer collected eight English curse words that were frequently used in movies. The same treatment was also considered in collecting twenty two indonesian curse words. The difference in numbers between the English and Indonesian cursing was considered to cover the participants' knowledge regarding the translation process of English cursing to Indonesian. Both the English and Indonesian curse words were used to formulate a questionnaire.

\subsection{Procedures}

In collecting the data of this present study, the participants were asked to answer a questionnaire. The questionnaire was divided into two parts, they are part A and part B. Part A of the questionnaire was used to study the background knowledge of the participants regarding the English language. They were asked about since when they studied English, whether they were familiar with English, and also whethet they were familiar with English and Indonesian cursing.

The part B of the questionnaire was used to study the knowledge of the participants regarding the English and Indonesian cursing. They were asked to judge whether the English and Indonesian curse words were very offensive, offensive, average, or noot offensive. Then, they were asked to translate the English curse words to Indonesian.

\section{Results and Discussion}

Based on the data analysis, it is found out that regarding the familiarity towards English, fourthy four participants (88\%) have learned English since elementary school. Meanwhile, five participants (10\%) have learned English since junior high school and only one participant (2\%) has learned English since high school. Further, thirty three participants (66\%) took English course outside the formal school, three participants (6\%) are taking English course, and fourteen participants (28\%) never learn English outside the formal school. From this point of view, it can be concluded that mostly the participants are quite familiar with English.

Regarding the English and Indonesian cursing, apparently the data show that fourty six participants (92\%) know about English cursing and only four participants (8\%) who do not know about English cursing. Thirty participants (60\%) answer that they know English cursing from western movies, three participants $(6 \%)$ from western songs, twenty participants $(40 \%)$ from friends, and only seven participants (14\%) who answer from when they learn English. This result suggests that most of participants recieve influences regarding the English cursing from western movies. Meanwhile, fourty eight participants (96\%) answer that they know Indonesian cursing and only two participants (4\%) do not know Indonesian cursing.

Related to the level of offensiveness of English cursing, the result is as following:

Table 1. Attitude towards the level of offensiveness of English cursing

\begin{tabular}{c|c|c|c|c|c}
\hline No. & $\begin{array}{c}\text { English Curse } \\
\text { Words }\end{array}$ & $\begin{array}{c}\text { Very } \\
\text { Offensive }\end{array}$ & Offensive & Average & Not Offensive \\
\hline 1. & Fuck/Fuck You & $33(66 \%)$ & $8(16 \%)$ & $4(8 \%)$ & $1(2 \%)$ \\
\hline 2. & Damn & $6(12 \%)$ & $11(22 \%)$ & $25(50 \%)$ & $2(4 \%)$ \\
\hline 3. & Bitch & $26(52 \%)$ & $11(22 \%)$ & $8(16 \%)$ & $1(2 \%)$ \\
\hline 4. & Shit & $6(12 \%)$ & $25(50 \%)$ & $13(26 \%)$ & $2(4 \%)$ \\
\hline 5. & Asshole & $25(50 \%)$ & $12(24 \%)$ & $8(16 \%)$ & $1(2 \%)$ \\
\hline 6. & Son of a Bitch & $31(62 \%)$ & $8(16 \%)$ & $6(12 \%)$ & $1(2 \%)$ \\
\hline 7. & Motherfucker & $33(66 \%)$ & $8(16 \%)$ & $4(8 \%)$ & $1(2 \%)$ \\
\hline 8. & Hell & $8(16 \%)$ & $24(48 \%)$ & $12(24 \%)$ & $2(4 \%)$ \\
\hline
\end{tabular}

Table 1. shows the attitude towards the level of offensiveness of English cursing based on the participants' judgement. Apparently, it is found out that 'Fuck/Fuck you', 'Bitch', 'Asshole', 'Son of a Bitch', and 'Motherfucker' are considered as very offensive cursing. Meanwhile, 'Shit' and 'Hell' are considered offensive, and only 'Damn' is considered average.

Table 2. Attitude towards the level of offensiveness of Indonesian cursing

\begin{tabular}{c|c|c|c|c|c}
\hline No. & $\begin{array}{c}\text { Indonesian Curse } \\
\text { Words }\end{array}$ & $\begin{array}{c}\text { Very } \\
\text { Offensive }\end{array}$ & Offensive & Average & Not Offensive \\
\hline 1. & Anjing & $34(68 \%)$ & $8(16 \%)$ & $5(10 \%)$ & $1(2 \%)$ \\
\hline 2. & Sial & $3(6 \%)$ & $9(18 \%)$ & $32(64 \%)$ & $4(8 \%)$ \\
\hline
\end{tabular}




\begin{tabular}{c|c|c|c|c|c}
\hline 3. & Brengsek & $9(18 \%)$ & $30(60 \%)$ & $8(16 \%)$ & $1(2 \%)$ \\
\hline 4. & Bajingan & $30(60 \%)$ & $12(24 \%)$ & $5(10 \%)$ & $1(2 \%)$ \\
\hline 5. & Binal & $31(62 \%)$ & $8(16 \%)$ & $7(14 \%)$ & $2(4 \%)$ \\
\hline 6. & Keparat & $29(58 \%)$ & $14(28 \%)$ & $4(8 \%)$ & $1(2 \%)$ \\
\hline 7. & Goblok & $14(28 \%)$ & $27(54 \%)$ & $6(12 \%)$ & $1(2 \%)$ \\
\hline 8. & Setan & $25(50 \%)$ & $14(28 \%)$ & $8(16 \%)$ & $1(2 \%)$ \\
\hline 9. & Tolol & $23(46 \%)$ & $12(24 \%)$ & $12(24 \%)$ & $1(2 \%)$ \\
\hline 10. & Bego & $11(22 \%)$ & $13(26 \%)$ & $25(50 \%)$ & $1(2 \%)$ \\
\hline 11. & Kurang Ajar & $6(12 \%)$ & $8(16 \%)$ & $31(62 \%)$ & $3(6 \%)$ \\
\hline 12. & Bedebah & $13(26 \%)$ & $26(52 \%)$ & $8(16 \%)$ & $1(2 \%)$ \\
\hline 13. & Babi & $29(58 \%)$ & $12(24 \%)$ & $6(12 \%)$ & $1(2 \%)$ \\
\hline 14. & Kampret & $8(16 \%)$ & $25(50 \%)$ & $12(24 \%)$ & $3(6 \%)$ \\
\hline 15. & Bangsat & $26(52 \%)$ & $14(28 \%)$ & $7(14 \%)$ & $1(2 \%)$ \\
\hline 16. & Monyet & $23(46 \%)$ & $10(20 \%)$ & $14(28 \%)$ & $1(2 \%)$ \\
\hline 17. & Tai & $31(62 \%)$ & $10(20 \%)$ & $6(12 \%)$ & $1(2 \%)$ \\
\hline 18. & Anjrit & $10(20 \%)$ & $9(18 \%)$ & $26(52 \%)$ & $3(6 \%)$ \\
\hline 19. & Bangke & $12(24 \%)$ & $12(24 \%)$ & $23(46 \%)$ & $1(2 \%)$ \\
\hline 20. & Koplok & $23(46 \%)$ & $12(24 \%)$ & $11(22 \%)$ & $2(4 \%)$ \\
\hline 21. & Edan & $11(22 \%)$ & $5(10 \%)$ & $31(62 \%)$ & $1(2 \%)$ \\
\hline 22. & Kunyuk & $7(14 \%)$ & $13(26 \%)$ & $26(52 \%)$ & $2(4 \%)$ \\
\hline
\end{tabular}

Table 2. shows the attitude towards the level of offensiveness of Indonesian cursing based on the participants' judgement. It is found out that 'Anjing', 'Bajingan', 'Binal', 'Keparat', 'Setan', 'Tolol', 'Babi', 'Bangsat', 'Monyet', 'Tai', and 'Koplok' are considered very offensive. Meanwhile, 'Brengsek', 'Goblok', 'Bedebah', and 'Kampret' are considered offensive. The rest of cursing, 'Sial', 'Bego', 'Kurang Ajar', 'Anjrit', 'Bangke', 'Edan', and 'Kunyuk' are considered average.

Table 3. Attitude towards translating English cursing to Indonesian

\begin{tabular}{c|c|c|c|c|c}
\hline No. & $\begin{array}{c}\text { English Curse } \\
\text { Words }\end{array}$ & Cursing & Literal & Not Aware & Concept \\
\hline 1. & Fuck/Fuck You & $41(82 \%)$ & $1(2 \%)$ & $5(10 \%)$ & $3(6 \%)$ \\
\hline 2. & Damn & $46(92 \%)$ & - & $4(8 \%)$ & - \\
\hline 3. & Bitch & $44(88 \%)$ & - & $4(8 \%)$ & $2(4 \%)$ \\
\hline 4. & Shit & $46(92 \%)$ & - & $4(8 \%)$ & - \\
\hline 5. & Asshole & $16(32 \%)$ & $27(54 \%)$ & $7(14 \%)$ & - \\
\hline 6. & Son of a Bitch & $9(18 \%)$ & $33(66 \%)$ & $8(16 \%)$ & - \\
\hline 7. & Motherfucker & $17(34 \%)$ & $24(48 \%)$ & $9(18 \%)$ & - \\
\hline 8. & Hell & $12(24 \%)$ & $32(64 \%)$ & $6(12 \%)$ & - \\
\hline
\end{tabular}

Table 3. shows the attitude towards translating English cursing to Indonesian. Apparently, most of participants translate the English curse words: Fuck/Fuck You, Damn, Bitch, and Shit to Indonesian cursing. They are aware that such words are curse words, thus they translate them to curse words in Indonesian. There is also another interesting result, there are participants who translate them literally, or translate them to 'concept' that is 'menggerutu' (to curse/to swear), and also there are those who do not know its translation in Indonesian.

In the case of 'Fuck/Fuck you' which is considered very offensive, most participants (twenty two/44\%) translate it to the word 'Setan/Persetan' - 'a general term of abuse' (Stevens and Schmidgall-Tellings, 2010, p. 927) which is also considered very offensive in Indonesian. The same happens to 'Damn', which is considered average, it is translated to the 'Sial' - 'cursed, damned' (Stevens and Schmidgall-Tellings, 2010, p. 931), which is also considered average (thirty nine/78\%). The same pattern is found in translating Bitch and Shit to Indonesian cursing. Bitch (very offensive) is translated to (fourthy four participants/88\%) 'Binal' (very offensive) - 'a wanton woman' (Stevens and SchmidgallTellings, 2010, p. 193). Shit (offensive) is translated to (fourty six participants/92\%) 'Tai/Taek' (very offensive) 'bullshit' (Stevens and Schmidgall-Tellings, 2010, p. 985). In this case, apparently, there is 'over-translated', that is Shit which is considered offensive is translated to 'Tai/Taek' which is considered very offensive in Indonesian. 
Meanwhile, in the case of Asshole, Son of a Bitch, Motherfucker, and Hell, most of participants translate them literally. Twenty seven participants (54\%) translate 'Asshole' literally as 'Lubang pantat' - ' the hole of anus' which is clear that it is not a curse word in Indonesian. The same occurs to the case of Son of A Bitch, Motherfucker, and Hell. 'Son of a bitch' is translated to (thirty three participants/66\%) 'Anak Jalang/Anak Haram' - 'illegitimate child' (Stevens and Schmidgall-Tellings, 2010, p. 33).'Hell' is translated to (thirty two participants/64\%) 'Neraka Jahanam' - 'the most hellish part of hell where infidels are put' (Stevens and Schmidgall-Tellings, 2010, p. 661). Further, 'Motherfucker' is translated (twenty four participants/48 \%) 'entot mama' - 'fuck your mother' or 'keparat ibu' - 'damn your mother'. This is obviously literal translation. In this process of literal translation, the cultural aspect, that is the level of offensiveness and the contextual meaning are not translated. This failure can affect the way the Indonesian young adults understand English cursing. The English curse words which are considered very offensive are understood less offensive. Thus, this may lead to the abuse of English cursing among the Indonesian.

\section{Conclusion}

The result of the present study shows that there are differences in translating the English curse words to Indonesian. There are two attitudes that can be observed. The first one is that the English curse words are translated to Indonesian curse words. This is adaptation method. This kind of method focuses on the cultural aspect. Thus, cultural aspects of source language are adapted to target language's. In this case, there is no interference found.

However, in the second attitude, there is interference involved. The second attitude towards translating English curse words to Indonesian shows that the English curse words are translated literally to Indonesian. The English curse words 'Asshole', 'Son of A Bitch', Motherfucker', and 'Hell', each of them is translated literally. Obviously, there is interference involved, that is interlingual interference. Although the participants know that such words are curse words (see Table 1.), apparently when it comes to the comparable words in Indonesian, the participants seem confused. They translate those words to the words they are familiar in Indonesian. Unfortunately, those familiar words in Indonesian cannot cover the contextual meanings of the English curse words. The context here refers to the fact that English cursing cannot be understood literally because the primary meanings of curse words are connotative not denotative ones Thus, translating English curse words literally to Indonesian is not suitable and can lead to the wrong way of understanding the concept of English cursing. From the data analysis above, it is clear that the most suitable method to translate cultural aspects such as cursing is the adaptation method, that is, curse words are translated to curse words again not literally as in the case of translating 'Fuck/Fuck You, Damn, Bitch, and Shit'. Yet, in the case of 'Asshole, Son of A Bitch, Motherfucker, and Hell', those words are translated literally as the effect of unfamiliar concept of new language so that they are translated literally in Indonesian that are familiar to the participants.

Thus, it can be concluded that the most significant interference involved in translating English curse words to Indonesian is interlingual interference that comes from the native language, in this case is Indonesian. Meanwhile, the most suitable method for translating English curing to Indonesian is adaptation based on Newmark (1988) because such method can cover the cultural aspect that cannot be covered by the other methods.

\section{Acknowledgements}

The present writer would like to thank to Lia Maulia Indrayani and Nani Darmayanti as the research advisers, also to Eva Tuckyta Sari Sujatna for her advice. Last but not least, I thank my brother, Riki Jaelani, and my friends, Bayu Permana Sukma, Alan Jaelani, Pebriwati Kaban, Erdisa Dipidua, Ida Lisdawati, and Ana for their help and advice.

\section{References}

ACS (The Australian Community Survey). (2013). [online] Available: http://www.ncls.org.au/default.aspx=2281 (March 25, 2013)

Al-Hassan, A. (2013). The importance of Culture in Translation: Should Culture be Translated? International journal of applied linguistics and English literature 2(2), 96-100. http://dx.doi.org/10.7575/aiac.ijalel.v.2n.2p.96

Bassnett, S. (2002). Translation Studies. London: Routledge.

Garcia, E.E. (2005). Teaching and Learning in Two Languages: Bilingualism \& Schooling in the United States. New York: Teacher College Press.

Hatim, B., \& Jeremy, M. (2004). Translation: An Advanced Resource Book. USA: Routledge.

Hughes, G. (2006). An Encyclopedia of Swearing. New York: M.E. Sharpe Inc.

Jay, T. (2000). Why We Curse: A Neuro-Psycho-Social Theory of Speech. Philadelphia: John Benjamin Publishing Company.

Jay, T., \& Kristin J. (2008). The Pragmatic of Swearing. Journal of Politeness Research, 4, 267-288. http://dx.doi.org/ 10.1515/JPLR.2008.013

Jekielek, S. \& Brett, B. (2005). The Translation to Adulthood: Characteristics of Young Adults Ages 18 to 24. USA: Annie E. Casey Foundation.

Leigh, M. \& Mike, L. (2005). Advance Swearing Handbook. Great Britain: Summersdale Publishers Ltd.

McManis, C. (1987). Language Files. Ohio: the Ohio States University Advocate Publishing Groups.

Newmark, P. (1988). A Text Book of Translation. UK: Prentice Hall.

Richards, Jack et al. (1985). Longman Dictionary of Applied Linguistics. UK: Longman Group Limited.

Sapolsky, Barry S. et al. (2008). Rating Offensive Words in Three Television Program Contexts. BEA 2008 Research Division.

Stevens, A. M., \& Schimdgall-Tellings, A. Ed. (2010). A Comprehensive Indonesian-English Dictionary: Second Edition. Ohio: Ohio University Press. 